\title{
Illegal Crossing of the Russian Federation State Border in the Siberian Federal District: Criminal Activity and Problems of Investigation
}

\author{
Alexander G. Volevodz a and Denis S. Khizhnyak ${ }^{\mathrm{b*}}$ \\ ${ }^{a}$ Moscow State Institute \\ of International Relations (MGIMO University) \\ Moscow, Russian Federation \\ ${ }^{b}$ Saratov State Law Academy \\ Saratov, Russian Federation
}

Received 24.11.2019, received in revised form 31.08.2020, accepted 25.09.2020

\begin{abstract}
The authors discuss the features of transnational criminal activity on the example of one of its varieties in the Siberian Federal District of the Russian Federation to highlight the criminal situation and criminal activity associated with illegal crossing of the Russian Federation state border. For the analysis of the specified criminal activity, sentences of courts of the District were studied and analyzed. The geographical factors influencing implementation of this criminal activity in the constituent entities of the Siberian Federal District, ways of crime concealment, combinatorics of various crimes and offences in the course of implementation of criminal activity, and also its long-term character showing in some cases are considered. Discussion of this issue can contribute to a more effective investigation of the considered category of crimes.
\end{abstract}

Keywords: transnational crimes, illegal crossing of the state border, Russian Federation, Siberian Federal District.

Research area: law.

Citation: Volevodz, A.G., Khizhnyak, D.S. (2020). Illegal crossing of the Russian Federation state border in the Siberian Federal District: criminal activity and problems of investigation. J. Sib. Fed. Univ. Humanit. Soc. Sci., 13(10), 1610-1617. DOI: 10.17516/1997-1370-0667.

(C) Siberian Federal University. All rights reserved

* Corresponding author E-mail address: a.volevodz@inno.mgimo.ru, denis_khizhnyak@mail.ru ORCID: 0000-0003-4962-2823 (Volevodz); 0000-0002-1377-6057 (Khizhnyak) 


\section{Introduction}

It is known that criminal situations in different regions can vary in their intensity and specific manifestations of criminal activities, so the interest of researchers in the specifics of crimes and criminal situations in each region of the country is only but natural. As for crimes in the Siberian Federal District, a number of books and articles published in the recent decades have been devoted to their study. They mainly relate to the issues of organized crime (Ostrovskikh, Kochedykova, 2018; Khristiuk, 2008; Shotkinov, 2004). However, no less important is the study of specific types of criminal activities, since they can reveal both common and varying features (Dubonosov et al., 2019; Rolik, 2010, etc.).

Transnational crimes represent a special category of criminal activity, the manifestations of which are also diverse. Such crimes differ not only in corpus delicti, but also in the characteristics of the subjects of criminal activity, transnational criminal relations, the degree of duration of implementation, etc.

Transnational criminal activity has its own "hot spots", which are the regions of the world or of a state, where transnational crimes are more frequent. The crisis conditions of national economies, the growth of unemployment, and the concentration of the unemployed in more prosperous national regions, in which, without finding a better use, they are involved in criminal activities, facilitate the development of transnational criminal activities at the national level. Having been formed in one state, criminal organizations are then able to extend their criminal activities to other states.

The significant threat caused by transnational crime to the security of states encourages theoretical debates involving the problems of transnational crimes and their classification (Albanese, 2011; Marmo, Chazal, 2016), their specific manifestations: corruption (Stefanuc, 2011), money laundering (Jderu, 2016), crimes in cyberspace (Buono, 2010, Velasco, 2015), trafficking in human organs (Francis, Francis, 2010), child trafficking (Sörensen, Nuyts, 2007), illegal migration (Spena, 2014), et al. The category of crimes related to illegal crossing of the Russian Federation state border is also important to characterize the manifestations of transnational criminal activity.

\section{Theoretical framework}

In 1995, the Ninth United Nations Congress on the Prevention of Crime and the Treatment of Offenders suggested a classification of crimes consisting of 18 types, the latter variety of them being designated as "other crimes" (ACONF.169.15.ADD.1). As this classification does not include illegal border crossing we may say that this classification is not exhaustive, and therefore, it can be supplemented with crimes under consideration.

The category of transnational crimes is not specified in the Criminal Code of the Russian Federation (1996), nor is the normative regulation of the place of criminal conduct. The difference between the international legal classification of transnational crimes and the classification of crimes in the Criminal Code of the Russian Federation does not facilitate a clearly structured information data base, is not helpful for a clear understanding of characteristics of such crimes and treatment of facts in investigative and judicial practice.

Another problem to be taken into account is the lack of a unified approach to the characterization of transnational crimes as a special category of crimes in jurisprudence.

Rather logical classification of crimes crossing the borders is given by M. Marmo and N. Chazal, who specify 1) domestic crimes that cross borders, 2) international crimes, 3) transnational crimes (2016: 5). Thus, the locus and vector factor is the leading one in highlighting all the main features of transnational crimes.

An important problem in identifying specific manifestations of transnational crimes is the semantic ambiguity of the terms "transnational" and "trans-boundary (cross-border)," which are often treated as synonyms. Sometimes cross-border crimes are considered as a separate category of transnational crimes (Godunov, 2008). However, it seems necessary to bring these terms into a system. Cross-border crimes are socially dangerous acts, individual episodes and stages of which are committed in the states with a common border. Thus, the concept of "cross-border 
crime" is narrower than the concept of "transnational crime," cross-border crimes being a kind of transnational crimes and having their own characteristics significant for their investigation. Identification of the subcategories of "cross-border crimes" determines the necessity for the designation of transnational crimes committed in states that do not have a common border. It is logical to treat such crimes as trans-territorial, i.e. as crimes committed in states that do not have a common border. The term trans-territorial already exists in the research works, e.g., in economic geography. Thus, discussing the issue of the necessity to identify "central places" in the world, where the process of globalization is most intensive, A.M. Trofimov and M.D. Sharygin state that such centers and their networks form a space that, on the one hand, is tied to certain places, and on the other, is a trans-territorial one, because it connects places that are geographically separated, but intensively interacting with each other (2009).

The modification of transnational crime classification is both of practical and theoretical importance, since the taxonomy with only one generic and one specific type is incomplete according to the rules of logic.

The situational approach to comparing the classification of transnational crimes with that in the Criminal Code of the Russian Federation (1996) allowed us to divide the latter into two groups: 1) unconditional transnational crimes (those that always include a transnational element), 2) conditional transnational crimes (those that may acquire a transnational character or may not). Besides, in transnational crime investigation practice one can find criminal acts, in corpus delicti of which one can detect emerging (optional) transnational elements.

\section{Statement of the problem}

The purpose of this article is to consider the criminal situation and the features of criminal activity associated with illegal crossing of the Russian Federation state border on the material of the Siberian Federal District.

The category of crimes connected with illegal crossing of the state border is enshrined in Article 322 of the Criminal Code of the Russian Federation (1996). According to the contents of Parts 1 and 2 of this Article, illegal crossing of the state border is understood as an action made without valid documents granting the right of entering the territory of the Russian Federation or departure from it, or without the proper permission received in the order provided for by the law of the Russian Federation, or as crossing the Russian Federation state border by a foreign citizen or a stateless person, whose entering the Russian Federation is obviously not allowed on the grounds provided for by the Russian Federation laws. Part 3 of Article 322 of the RF Criminal Code states that illegal crossing of the Russian Federation state border may be committed by one person, or a group of persons by prior agreement, or by an organized group.

It is obvious that these crimes constitute a specific category, and their implementation may differ in the Russian Federation constituent entities, because these entities or their administrative territorial units may have or have no common border with other states. Administrative territorial units of the Siberian Federal District have different remoteness from the state border of Russia with other states. Therefore, the study of the nature of manifestation of criminal activity associated with illegal crossing of the Russian Federation state border has both practical and theoretical significance for criminology, criminal law, and forensic science.

\section{Methods}

Based on the principle of unity of theory and practice we analyze the cases considered by the courts of general jurisdiction and the Supreme Courts of the Republics in the constituent entities of the Siberian Federal District from 2011 to 2018. One may find these cases on two websites (Gcourts.ru, Sud.Praktika.ru). Although these databases of court cases are obviously incomplete, we identified 147 sentences passed under Article 322 of the RF Criminal Code. The analysis of this number of cases and their nature make it possible to achieve the outlined objectives of the article. 


\section{Discussion}

The analysis of the cases shows that transnational crimes of the considered category committed in the Siberian Federal District can be both cross-border and trans-territorial. In the former case, an illegal crossing of the Russian Federation state border can be carried out using land vehicles (cars, buses, trains), or on foot in a place, which is not meant for the legal crossing of the border (as it often happens in the Omsk and Novosibirsk oblasts, the Altai Territory, and the Altai Republic), or on horseback (as in the Republic of Tuva). In the latter case, the RF state border is crossed by air.

Cross-border crimes are committed by foreign citizens, citizens of the Russian Federation, and stateless persons. The percentage of the first category of persons accounts for $88.3 \%$ of the total number of the analyzed cases. Only $7.5 \%$ of such crimes were committed by women and $5.4 \%$ - by groups of persons united by a prior conspiracy, whereas the rest of them were committed by men.

The geographical location of the Siberian Federal District determines the fact that $83.9 \%$ of illegal crossings of the state border of Russia carried out by foreign citizens and stateless persons were committed by natives of Kazakhstan and China. In other cases, the residents from Uzbekistan, Kyrgyzstan, Tajikistan and Turkmenistan entered Russia through the border of the Republic of Kazakhstan. Chinese citizens illegally entered the territory of the Siberian Federal District (Krasnoyarsk and Irkutsk) by air.

The aims of committing crimes according to their qualification by the courts were diverse. Russian citizens illegally crossed the border to purchase consumer goods in another state at a lower price (that is, with a selfish motive) or to return to the territory of Russia and continue working, to commit a theft of other people's property (usually cattle), for illegal acquisition, transportation and storage of drugs, and for the purpose of fishing or hunting (especially in Mongolia).

Foreign citizens and stateless persons illegally crossed the Russian Federation border from a foreign state for the purpose of finding better living conditions, obtaining a migration card, extending their stay in Russia, visiting relatives who are citizens of the Russian Federation, employment, evading criminal responsibility for the crimes of which they were accused of in their native countries, and illegal transportation of narcotic drugs.

Some purposes of crime commission are specific for a certain constituent entities of the Siberian Federal District. For example, illegal border crossing for the purpose of cattle theft is committed only on the territory of Mongolia by the inhabitants of Tuva.

Most of the crimes were not completed due to the circumstances beyond the control of the offenders, as their actions were stopped by border control officers or border patrol as a result of timely detection of the existing ban for a person to cross the state border of the Russian Federation. The crimes committed without valid documents for the right to enter the Russian Federation and leave its territory without proper permission obtained in accordance with the legislation of the Russian Federation are numerous. However, 12\% of such crimes were detected after the crime had already been committed. Those were mainly the cases when offenders used forged or someone else's documents, or crossed the Russian Federation state border bypassing the existing checkpoints. These facts also indicate the variety of ways of crime concealment: 1) falsification - the use of forged documents, 2) disguise when a person crosses the border bypassing the checkpoints, 3) the combination of falsification with disguise when a person uses other people's documents.

Materials of the studied cases give us the reason to state that some criminal acts are characterized by some degree of duration, and also by a combination of various types of crimes and administrative offenses allowing to characterize such crimes as "criminal activity" the category of forensic science which unlike the category of "crime" is characterized by the above manifestations (Solov'ev, Kobzeva, 2001: 240-241).

The most common crimes under Article 322 of the RF Criminal Code are accompanied by such crimes as theft (Article 158 of the RF Criminal Code), illegal acquisition, stor- 
age, transportation, manufacture, processing of narcotic drugs, psychotropic substances or their analogues, as well as illegal acquisition, storage, transportation of plants containing narcotic drugs or psychotropic substances, or parts thereof containing narcotic drugs or psychotropic substances (Article 228 of the RF Criminal Code), forgery, production or turnover of forged documents, state awards, stamps, seals or forms (article 327 of the RF Criminal Code). Sometimes the illegal border crossing is accompanied by violating the Code of Administrative Offences of the Russian Federation (2001) (Article 18.2 - violation of border regime in border zone and Article 18.8 - violation of the rules of entering the Russian Federation or the regime of residence in the Russian Federation by a foreign citizen or a stateless person).

Duration of crime commission is one more characteristic feature of the category of "criminal activity", which is a rather typical phenomenon in the sphere of its implementation. This phenomenon can be exemplified by the cases tried in the Siberian Federal District.

Example 1. In one of the cases considered by the Karasuksky district court of the Novosibirsk Oblast, 17 episodes of illegal crossing of the Russian Federation state border by the same person, a citizen of the Republic of $U z-$ bekistan, were described. All the crimes were committed in Karasuksky district of the Novosibirsk Oblast and in the Altai Territory over an extended period. In the court decision it was stressed that every time this person had crossed the state border of the Russian Federation without proper authorization obtained in the manner prescribed by the legislation of the Russian Federation.

Example 2. The Supreme Court of the Republic of Altai considered the criminal case against a group of five persons who illegally crossed the state border of the Russian Federation from Russia to the Republic of Kazakhstan and back using foreign passports belonging to other citizens of the Russian Federation with the registered residence in a settlement of the border territory. According to the Agreement between the Government of the Russian Federation and the Government of the Republic of Kazakhstan this fact gives the right to those who live in the settlements adjoining the border to cross it without other permissions (Soglashenie..., 2006).

Example 3. The long-term nature of the crime was found in one of the sentences of the Oktyabrsky district court of Irkutsk. It describes the repeated trespassing of the state border of Russia at air checkpoints by a citizen of Tajikistan with false documents.

\section{Conclusion}

Transnational criminal activity is diverse and specific in its manifestations in different regions of Russia. It depends on their geographical location. Thus, special consideration of each type of criminal activity in terms of its implementation in the constituent entities of the Russian Federation is important to identify the specifics of the criminal situation and the practice of crime detection and investigation.

The distinction between cross-border and trans-territorial crimes in the overall system of transnational criminal acts is not only of theoretical importance. It also contributes to a more detailed analysis of the criminal situation and the practice of investigating such crimes, which is also important for improving the statistical processing of crime data in Russia as a whole.

The analysis of cases considered by courts and related to illegal crossing of the Russian Federation state border on the example of the Siberian Federal District revealed not only the generic specifics of transnational criminal activities (combinatorics of crimes during implementation of criminal activity and its duration). The analysis also allows us to conclude that in the investigative practice there are certain problems associated with identifying the individuals, who are prohibited to enter Russia, and ways of crime concealing, as well as the identification of the most frequently used routes for bypassing the established border checkpoints of the Russian Federation by the criminals. This conclusion can contribute to the development of specific measures in this region of Russia aimed at improving the investigation practice. 


\section{References}

ACONF.169.15.ADD.1. 4 April, 1995. Retrieved February 7, 2019. Available at: http://www.unodc.org/ documents/congress//Previous_Congresses/9th_Congress_1995/017_ACONF.169.15.ADD.1_Interim_Report_Strengthening_the_Rule_of_Law.pdf (accessed 20 October 2019).

Albanese, J.S. (2011). Transnational Crime and the 21 ${ }^{\text {st }}$ Century: Criminal Enterprise, Corruption, and Opportunity. Oxford University Press, $176 \mathrm{p}$.

Buono, L. (2010). Investigating and prosecuting crimes in cyberspace: European training schemes for judges and prosecutors. In ERA Forum, 16 (3), 207-218. DOI: 10.1007/s12027-010-0161-0.

Dubonosov, E.S., Bugaevskaya, N.V., Volchetskaia, T.S., Vlasenko, V.N. (2019). The problems of perfecting of anticorruption legislation and activity of law-enforcement agencies on struggle with corrupt practice in the regions of Siberia and the Central Russia. In J. Sib. Fed. Univ. Humanit. soc. sci., 12 (6), 918-924. DOI: 10.17516/1997-1370-0429.

Francis, L.P., Francis, J.G. (2010). Stateless Crimes, Legitimacy, and International Criminal Law: The Case of Organ Trafficking. In Criminal Law and Philosophy, 4, 283-295. DOI: 10.1007/s11572-010-9100-y.

Gcourts.ru. Available at: http://www.gcourts.ru/ (accessed 20 October 2019).

Godunov, S.V. (2008). Rossiisko-kazakhskoe sotrudnichestvo v sfere obespecheniia pogranichnoi bezopasnosti (konets 1990-kh - pervaia dekada 2000-kh godov [Russian-Kazakh cooperation in border security (late 1990s - the first decade of 2000s]. In Vestnik Volgogradskogo gosudarstvennogo universiteta. Ser. 4. Istoriia [Bulletin of the Volgograd State University. Ser. 4. History], 2 (14), 70-80.

Jderu, C. (2016). Money laundering, confiscation, freezing and seizing of proceeds of crime. Romanian perspective. Human rights issues. In ERA Forum, 17, 287-297. DOI: 10.1007/s12027-016-0437-0.

Khalliulin, A.I. (2012). Mesto soversheniia prestupleniia kak priznak sostava prestupleniia $\mathrm{v}$ sfere komp'iuternoi informatsii [Place of crime as a sign of a crime in the field of computer information]. In $A k$ tual'nye problemy èkonomiki i prava [Topical problems of Economics and Law], 1 (21), 291.

Khristiuk, A.A. (2008). Organizovannaia prestupnost': sovremennye tendentsii i regional'nye osobennosti: po materialam Vostochnoi Sibiri: avtoreferat dis. ... kandidata iuridicheskikh nauk [Organized crime: current trends and regional features: based on the materials of Eastern Siberia. ... Abstract of thesis of PhD in law]. Irkutsk, 23.

Kodeks Rossiiskoi Federatsii ob administrativnykh pravonarusheniiakh [Code of Administrative Offences of the Russian Federation] (2001). Available at: http://www.consultant.ru/document/cons_doc_ LAW 34661 (accessed 20 October 2019).

Marmo, M., Chazal N. (2016). Transnational Crime and Criminal Justice. New York: SAGE Publications Ltd., 240 p.

Ostrovskikh, Zh.V., Kochedykova, D.A. (2018). Preduprezhdenie organizovannoi prestupnosti v Vostochnoi Sibiri [Prevention of organized crime in Eastern Siberia]. In Kriminologicheskie chteniia: Materialy 13 Vserossiiskoi nauchno-prakticheskoi konferentsii s mezhdunarodnym uchastiem, posviashchennoi 90-letiiu zasluzhennogo iurista Rossiiskoi Federatsii i Respubliki Buriatiia, professora B.Ts. Tsydenzhapova [Proc. 13 All-Russian scientific and practical conference with international participation dedicated to the 90th anniversary of the honored lawyer of the Russian Federation and the Republic of Buryatia, Professor B.Ts. Tsydenzhapov]. Ulan-Ude:: Izd-vo Buriatskogo gos. un-ta, 132-141.

Rolik, A.I. (2010). Kriminalisticheskaia i meditsinskaia otsenki narkosituatsii na Dal'nem Vostoke [Forensic and medical assessment of drug situation in the Far East]. In Nauchno-analiticheskii zhurnal Obozrevatel' - Observer [Scientific and analytical journal Observer], 2 (241), 35-41.

Shotkinov, S.A. (2004). Prestupnost'v krupnykh gorodakh Vostochnoi Sibiri [Crime in large cities of Eastern Siberia]. Saint-Peterburg: Iuridicheskii tsentr Press, 221.

Soglashenie mezhdu Pravitel'stvom Rossiskoi Federatsii i Pravitel'stvom Respubliki Kazakhstan o poriadke peresecheniia rossiisko-kazakhstanskoi gosudarstvennoi granitsy zhiteliami prigranichnykh territorii Rossiiskoi Federatsii i Respubliki Kazakhstan [Agreement between the Government of the Russian Federation and the Government of the Republic of Kazakhstan on the procedure for crossing the Rus- 
sian-Kazakh state border by residents of the border territories of the Russian Federation and the Republic of Kazakhstan]. (2006). Available at: https://base.garant.ru/1157155/ (accessed 20 October 2019).

Solov'ev, A.V., Kobzeva, I.A. (2001). Kriminal'naia i kriminalisticheskaia deiatel'nost' kak ob'ekt izucheniia kriminalistiki [Criminal and forensic activity as an object of study of analysis in criminology]. In Rossiiskaia iuridicheskaia doktrina $v$ XXI veke: problemy i puti ikh resheniia: materialy nauchno-prakticheskoi konferentsii (3-4 oktiabria 2001 g.) [Proc. of the scientific and practical conference "Russian legal doctrine in the XXI century: problems and solutions"']. Saratov: SGAP, 240-241.

Sörensen, P., Nuyts, G. (2007). Cases of Child Trafficking. In ERA Forum, 8, 481-494. DOI: 10.1007/ s12027-007-0036-1.

Spena, A. (2014). Criminalization of Immigrants and the Basic Principles of the Criminal Law. In Criminal Law and Philosophy, 8, 635-657. DOI: 10.1007/s11572-013-9229-6.

Stefanuc, R. (2011). Corruption, or how to tame the shrew with the European Union stick: the new anti-corruption initiative of the European Commission. In ERA Forum, 12, 427-443. DOI: 10.1007/s12027011-0231-y.

Sud.Praktika.ru [Judicial practice]. Available at: https://sud-praktika.ru/precedent/category/86.htm$1 ? \mathrm{p}=1$ (accessed 20 October 2019).

Trofimov, A.M., Sharygin, M.D. (2009). Global'nye goroda: perspektivy razvitiia. Retsenziia na knigu «Global'nyi gorod: teoriia i real'nost' [Global cities: prospects for development. Review of the book "Global city: theory and reality"]. In Geograficheskii vestnik [Geographical Bulletin], 3 (11), available at: https:// www.elibrary.ru/download/elibrary_15584105_13872353.pdf (accessed 20 October 2019).

Ugolovnyi kodeks Rossiiskoi Federatsii [Criminal Code of the Russian Federation] (1996). Available at: http://www.consultant.ru/document/cons_doc_LAW_10699/(accessed 20 October 2019).

Velasco, C. (2015). Cybercrime jurisdiction: past, present and future. In ERA Forum, 16, 331-347. DOI: 10.1007/s12027-015-0379-y. 


\title{
Незаконное пересечение
}

\section{государственной границы Российской Федерации}

в Сибирском федеральном округе:

\section{криминальная деятельность и проблемы расследования}

\author{
А.Г. Волеводз ${ }^{\mathrm{a}}$, Д.С. Хижняк ${ }^{6}$ \\ ${ }^{a}$ Московский государственный институт \\ международных отношений \\ Российская Федеращия, Москва \\ ${ }^{6}$ Саратовская государственная юридическая академия \\ Российская Федерачия, Саратов
}

\begin{abstract}
Аннотация. Рассмотрены особенности осуществления транснациональной криминальной деятельности на примере одной ее разновидности в Сибирском федеральном округе РФ для освещения криминогенной ситуации и криминальной деятельности, связанной с незаконным пересечением государственной границы РФ. Для анализа указанной криминальной деятельности привлечены приговоры судов региона, рассмотрены географические факторы, влияющие на осуществление рассматриваемой криминальной деятельности в разных субъектах Сибирского федерального округа, способы сокрытия преступлений, их комбинаторика в ходе осуществления криминальной деятельности, а также проявляющийся в ряде случаев ее длящийся характер. Обсуждение указанной проблемы может способствовать более эффективному расследованию рассмотренной категории преступлений.
\end{abstract}

Ключевые слова: транснациональные преступления, незаконное пересечение государственной границы, Российская Федерация, Сибирский федеральный округ.

Научная специальность: 12.00.00 - юридические науки. 